\title{
Controlling shareholder share pledging and Enterprise Cost Stickiness: Evidence from Chinese Firms
}

\author{
Ziyang $\mathrm{Li}^{1}{ }^{1, \mathrm{a}}$, Yingyue Zhang ${ }^{2, \mathrm{~b}}$, Xiaohan $\mathrm{Tan}^{3, \mathrm{c}}$, Wen $\mathrm{Yu}^{4, \mathrm{~d} *}$ \\ ${ }^{1}$ Business School, Sichuan University, Chengdu, China \\ ${ }^{2}$ Business School, Sichuan University, Chengdu, China \\ ${ }^{3}$ Business School, Sichuan University, Chengdu, China \\ ${ }^{4}$ Sichuan Branch, Industrial and Commercial Bank of China Limited, Chengdu, China
}

\begin{abstract}
Using a sample of Chinese enterprises pledge during the period 2008-2017, this paper investigates the cost management behavior of enterprises during the pledge period of major shareholders' stock rights. Our findings show that with the increase of the equity pledge rate, the cost stickiness of enterprises is enhanced. Further analysis shows that the behavior that the controlling shareholder invests the equity pledge funds to a third party weakens the cost stickiness of the enterprise. We further contribute to the literature on sticky cost and equity pledge by discussing the strategic choices of major shareholders to avoid risks during the equity pledge period.
\end{abstract}

\section{Introduction}

Cost stickiness represents asymmetric cost behavior, and is often embedded into cost forecasting in existing studies. As a means of financing, share pledge has brought a series of risks which have gradually attracted the attention of enterprise managers and regulatory departments. The existing researches mainly studies the influencing factors of cost stickiness from the level of managers, such as adjustment cost, optimistic expectation of managers, opportunism of managers, etc., but research on cost stickiness directly from the perspective of enterprise investment and financing is largely neglected. With the generalization of China's equity pledge market, the convenience of equity pledge to solve the financing constraints of enterprises has attracted more and more attention. So, will the cost stickiness of enterprises be affected by the change of financing constraints? At the same time, a series of risk problems brought by equity pledge also need to be solved urgently. In the face of such risks, what kind of expectations will enterprise managers have?

The data of companies with equity pledge from 2008 to 2017 is taken as sample in this paper, the equity pledge rate and the direction of the equity pledge funds are selected to reflect the situation of equity pledge. The ordinary least square (OLS) method is used to conduct empirical research to explore the relationship between equity pledge and cost stickiness based on the idea of ABJ. The results show that the equity pledge rate is positively correlated with the cost stickiness. However, when the controlling shareholder invests the pledge funds to a third party, the positive correlation is weakened.

Theoretically speaking, this paper complements the study on share pledge and cost stickiness from the perspectives of controlling shareholders and managers. From the view of shareholder financing, this paper provides a new way for revealing the enterprise's cost management behavior. Practically speaking, this paper studies on how to avoid the risk of share pledge in the practice of Chinese enterprises, thus affecting cost stickiness, which is beneficial for enterprises. The relationship between financial institutions and enterprises is strengthened by reducing the asymmetry of the information obtained, thus the purpose of broadening the financing channels of enterprises is achieved.

\section{Literature review, theoretical analysis and research hypothesis}

Existing researches show that the risk of equity pledge mainly caused by the decline of stock price(Hao \& Liang, 20097; Xie, Zheng, \& Cui, 201617; Xu, He, \& Chen, 201618). Therefore, controlling shareholders usually take a series of measures to prevent stock prices from falling, such as information disclosure, profit distribution, earnings management, reasonable tax avoidance, innovation investment and other aspects(Xie, Liao, \& Zheng, 201716; Jiang, $\mathrm{Hu} \& \mathrm{Lv}, 20159)$. At the same time, new conflicts of interest to securities analysts will be brought by the risk of share pledge, and affect the auditor's pricing strategy(Tan \& Wu, 201315). Share pledge solves the problem of financing constraints that is urgently need to solve(Li \& Zheng, 201511), which will

alzy_feng@scu.edu.cn; ${ }^{\mathrm{b}} \mathrm{zhang}$ yingyue@foxmail.com; ${ }^{\mathrm{c}}$ cici_tan97@163.com; ${ }^{\mathrm{d}} \mathrm{vane}$ _yu@sina.cn 
affect managers' expectations for the future of the company.

Cost stickiness is an important issue in the category of cost behavior, accurate identification of the factors that affect cost stickiness is of great significance to improve the efficiency and value of the company(Jiang $\& \mathrm{Hu}, 20118)$. The impact of managers on cost stickiness has been investigated, including the company's business strategy, the subjective factors of company size and sales revenue and managers, the level of corporate social responsibility and so on (Liang, 201512; Balakrishnan et al., 20141; Banker, Basu, Byzalov, \& Chen, 20143; Banker \& Byzalov, 20142; Banker, Byzalov, Ciftci \& Mashruwala, 20144; Brüggen \& Zehnder, 20145; Habib \& Hasan, 20196). However, there is still a lack of research on the impact of investment and financing behavior on cost stickiness from the perspective of controlling shareholders.

The problem of financing constraints of enterprises can be solved by equity pledge. With the equity pledge, more capital resources is get to expand business. Besides, with the expansion of the business scale, more excessive investment resources is mastered by managers to control freely. When the sales performance of the enterprise is good, managers' optimistic expectations will lead them to expand the size of the enterprise, this kind of behavior based on the interests of managers will undoubtedly enhance the cost stickiness(Kong, Zhu \& Kong, 200710).

The risk brought by share pledge has been concerned by more and more scholars. A large number of researches show that cost stickiness is impacted by corporate social responsibility activities, financing management constraints, accrued earnings management, corporate productivity, mergers and the confidence of managers(Ma \& Zhang, 201313; Balakrishnan, 20141; Banker, 20142; Banker, 20143; Brüggen, 20145; Habib, 20196; Jiang, 20159; Kong, 200710; Liang, 201512; Ma, 201313; Qin, Mohan \& Kuang, 201514; Yang, 201519). Specifically, for cost stickiness, when the business volume of an enterprise decreases, managers will reduce the adjustment cost of reducing business volume by reducing the current redundant resources, and reduce the possibility of future business recovery, because the upward cost of committed resources is lower than that of committed resources. So when the controlling shareholders of the company have share pledge and invest the funds to a third party, what kind of adjustment will the enterprise make to the cost management due to the change of financing constraints? As a result, will managers be more pessimistic about the future of the enterprise? How will this change the impact of share pledge rate on cost stickiness?

This paper puts forward the following two hypotheses to test the impact of equity pledge on cost stickiness:

Hypothesis 1: The equity pledge rate is positively correlated with the cost stickiness.

Hypothesis 2: When equity pledge funds are invested in third parties, the correlation between equity pledge rate and cost stickiness will be weakened.

\section{Data model and research design}

\subsection{Data Sources and Variable Selection}

This paper selects the Chinese companies that have carried out equity pledge from 2008 to 2017 as the initial sample, and the data is taken from the database of CSMAR. The total sample size is 5917. There are 2237 companies whose funds pledged by the controlling shareholders are invested in themselves, and 4209 companies occur a decline in sales revenue.

\subsection{Model Design}

Based on the idea of ABJ, this paper uses the Ordinary Least Square (OLS) method and the following models (1), (2) and (3) to test whether and how the controlling shareholder equity pledge affects the cost stickiness of the enterprise.

$\Delta I n$ Cost $_{i, t}=\beta_{0}+\beta_{1} \Delta I n S A L E S_{i, t}+\beta_{2} D E C_{i, t} \Delta \operatorname{InSALES}+$

$\beta_{3} P \lg$ rate $_{i, t} \times D E C_{i, t} \Delta I n S A L E S+\beta_{4} A I N T_{i, t} \times D E C_{i, t} \Delta I n S A L E S+$ $\beta_{5} E I N T_{i, t} \times D E C_{i, t} \Delta I n S A L E S+\beta_{6} F C F_{i, t} \times D E C_{i, t} \Delta I n S A L E S$

$\Delta$ In ost $_{i, t}=\beta_{0}+\beta_{1} \Delta \operatorname{InSALES} S_{i, t}+$

$\beta_{2} \times D E C_{i, t} \Delta I n S A L E S+\beta_{3} P \lg$ rate $_{i, t} \times D E C_{i, t} \Delta I n S A L E S+$

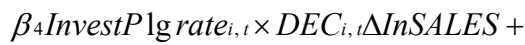

$\beta_{5} A I N T_{i, t} \times D E C_{i, t} \Delta I n S A L E S+$

$\beta_{6} E I N T_{i, t} \times D E C_{i, t} \Delta I n S A L E S+\beta_{7} F C F_{i, t} \times D E C_{i, t} \Delta I n S A L E S$

$\Delta$ InCost $_{i, t}=\beta_{0}+\beta_{1} \Delta \operatorname{InSALES} \mathrm{S}_{i, t}+$

$\beta_{2} \times D E C_{i, t} \Delta I n S A L E S+\beta_{3} H H I \times D E C_{i, t} \Delta I n S A L E S+$

$\beta_{4} P \lg$ rate $_{i, t} \times D E C_{i, t} \Delta \operatorname{InSALES}+\beta_{5} A I N T_{i, t} \times D E C_{i, t} \Delta I n S A L E S+$

$\beta_{6} E I N T_{i, t} \times D E C_{i, t} \Delta I n S A L E S+\beta_{7} F C F_{i, t} \times D E C_{i, t} \Delta I n S A L E S$

In the model, $\beta_{0}$ represents the constant term, $\beta_{1}-\beta_{7}$ represents the coefficient, and $\mathrm{t}$ represents the time subscript. The definition and measurement of variables used in this model are shown in Table 1.

TABLE I. THE DEFINITION AND MEASUREMENT OF VARIABLES

\begin{tabular}{|c|c|c|}
\hline $\begin{array}{l}\text { Variable } \\
\text { symbol }\end{array}$ & $\begin{array}{l}\text { Variable } \\
\text { definition }\end{array}$ & Variable measurement \\
\hline$\Delta \mathrm{InCost}$ & $\begin{array}{l}\text { Rate of } \\
\text { change in } \\
\text { operating } \\
\text { costs }\end{array}$ & $\begin{array}{l}\Delta \ln C o s t i, t=\log (\operatorname{Costi}, \quad t / \\
\text { Costi, } \mathrm{t}-1)\end{array}$ \\
\hline $\begin{array}{l}\Delta \text { InSALE } \\
\mathrm{S}\end{array}$ & $\begin{array}{l}\text { Rate of } \\
\text { change in } \\
\text { sales } \\
\text { revenue }\end{array}$ & $\begin{array}{l}\Delta \ln S A L E S i, \\
\mathrm{t}=\log (\mathrm{SALESi}, \mathrm{t} \\
/ \mathrm{SALESi}, \mathrm{t}-1)\end{array}$ \\
\hline DEC & $\begin{array}{l}\text { Dummy } \\
\text { variable of } \\
\text { sales }\end{array}$ & $\begin{array}{l}\text { If sales revenue is } \\
\text { reduced in the current } \\
\text { period, } \\
\mathrm{DEC}=1,\end{array}$ \\
\hline
\end{tabular}




\begin{tabular}{|c|c|c|}
\hline $\begin{array}{l}\text { Variable } \\
\text { symbol }\end{array}$ & $\begin{array}{l}\text { Variable } \\
\text { definition }\end{array}$ & Variable measurement \\
\hline & change & otherwise $\mathrm{DEC}=0$ \\
\hline Plgrate & $\begin{array}{l}\text { Pledge } \\
\text { rate }\end{array}$ & $\begin{array}{l}\text { Cumulative number of } \\
\text { pledged shares / number } \\
\text { of shares held by major } \\
\text { shareholders at the end } \\
\text { of the year }\end{array}$ \\
\hline Invest & $\begin{array}{l}\text { The } \\
\text { orientation } \\
\text { of equity } \\
\text { pledge to } \\
\text { raise funds }\end{array}$ & $\begin{array}{l}\text { If the funds raised in the } \\
\text { current period are only } \\
\text { invested in itself, } \\
\text { Invest }=0, \quad \text { otherwise } \\
\text { Invest }=1\end{array}$ \\
\hline EINT & $\begin{array}{l}\text { Equity } \\
\text { intensity }\end{array}$ & $\begin{array}{l}\text { EINT }=\log (\text { Equity/Sales } \\
\text { revenue) }\end{array}$ \\
\hline AINT & $\begin{array}{l}\text { Asset } \\
\text { intensity }\end{array}$ & $\begin{array}{l}\text { AINT }=\log (\text { Total } \\
\text { assets/Sales revenue })\end{array}$ \\
\hline FCF & $\begin{array}{l}\text { Asset free } \\
\text { cash ratio }\end{array}$ & $\begin{array}{l}\mathrm{FCF}=\text { Free } \\
\text { flow/Total assets }\end{array}$ \\
\hline HHI & $\begin{array}{l}\text { Herfindahl } \\
\text { index }\end{array}$ & $\begin{array}{l}H H I=\sum_{i=1}^{n} p_{i}^{2}, \mathrm{Pi} \text { is the } \\
\text { proportion of industry } \\
\text { revenue in total revenue }\end{array}$ \\
\hline
\end{tabular}

\section{Empirical result and analysis}

\subsection{Regression Analysis of the Relationship between the Equity Pledge Rate and Cost Stickiness}

Table 2 reports the regression results of Hypothesis 1. In column (1) of Table 3, tshe regression coefficient of $\triangle$ InSALES is negative and significantly positive at $1 \%$ level, while the regression coefficient of DEC* $\Delta$ lnSales is negative and significantly positive at $1 \%$ level, which indicates that the operating costs of Chinese enterprises are "sticky". The results are consistent with the research results of Anderson et al. (2003) and Sun Zheng, Liu Hao et al. (2004). According to the existing studies, this paper uses Total asset concentration (AINI) and shareholder's equity concentration (EINT) as cost agency variables, and free cash flow (FCF) as measurement variables of agency costs.

Based on the basic research model of cost stickiness, equity pledge rate is introduced as an explanatory variable to carry out multiple regression to model (1). The specific regression results are shown in Table 3 . The results in column(1) table 3 show that the parameter estimated value of equity pledge rate is -0.009 , which is significantly positively correlated at $1 \%$ level. The results support Hypothesis 1 proposed, that the higher the equity pledge rate, the stronger the cost stickiness. It can be seen that when the equity pledge rate is high, managers are more inclined to radical business strategies, and the internal capital flow is faster and abundant. This series of actions will lead to the increase of enterprise cost stickiness.
TABLE II. THE REGRESSION RESULT OF THE EQUITY PLEDGE RATE AND COST STICKINESS

\begin{tabular}{|c|c|c|}
\hline Variable & $\begin{array}{l}\text { Regressio } \\
\text { n }\end{array}$ & Regression(1) \\
\hline Cons & $\begin{array}{r}0.094 * * * \\
(22.09)\end{array}$ & $\begin{array}{r}0.095 * * * \\
(22.39)\end{array}$ \\
\hline$\Delta \operatorname{lnSALES}$ & $\begin{array}{r}0.443 * * * \\
(57.14)\end{array}$ & $\begin{array}{r}0.442 * * * \\
(57.10)\end{array}$ \\
\hline $\begin{array}{l}\text { DEC* } * \ln S A \\
\text { LES }\end{array}$ & $\begin{array}{c}-0.165^{* * *} \\
(-6.59)\end{array}$ & $\begin{array}{c}-0.095^{* * *} \\
(-3.33)\end{array}$ \\
\hline $\begin{array}{l}\text { Plgrate*DEC } \\
* \Delta \operatorname{lnSALES}\end{array}$ & & $\begin{array}{c}-0.009^{* * *} \\
(-5.17)\end{array}$ \\
\hline $\begin{array}{l}\text { AINT*DEC } \\
* \Delta \operatorname{lnSALES}\end{array}$ & $\begin{array}{l}0.000 \\
(1.75)\end{array}$ & $\begin{array}{l}0.000 \\
(1.26)\end{array}$ \\
\hline $\begin{array}{l}\text { EINT*DEC* } \\
\Delta \operatorname{lnSALES}\end{array}$ & $\begin{array}{c}-0.032 * * * \\
(-3.93)\end{array}$ & $\begin{array}{c}-0.031 * * * \\
(-3.74)\end{array}$ \\
\hline $\begin{array}{l}\text { FCF*DEC* } \\
\Delta \operatorname{lnSALES}\end{array}$ & $\begin{array}{c}0.074 \\
(0.5)\end{array}$ & $\begin{array}{c}0.018 \\
(0.13)\end{array}$ \\
\hline $\begin{array}{l}\text { F statistic } \\
\text { Adjusted R2 } \\
\text { N }\end{array}$ & 769.33 & 648.26 \\
\hline \multirow[t]{2}{*}{ HHI } & 0.394 & 0.396 \\
\hline & 5917 & 5917 \\
\hline
\end{tabular}

\subsection{Regression Analysis of the Relationship between Equity Pledge Funds Invested in Third Parties, Equity Pledge Rate and Cost Stickiness}

Model (2) is used to test whether the equity pledge capital is invested to the third party and its influence of the equity pledge rate on the cost stickiness relationship. The regression results can be seen from Table 4 . The parameter estimated value of $\beta_{3}$ is -0.009 , which is significant at $1 \%$ level, while the estimated value of $\beta_{4}$ parameter is 0.020 , significant at $5 \%$ level. The result also supports Hypothesis 2, may caused by the following two reasons. First, the funds of equity pledge financing are invested in a third party, so that the self-regulated resources within the company can not be satisfied when the sales volume drops, and the enterprise will appropriately reduce the committed resources that have been invested. Second, the investment of equity pledge funds to the third party enhances the managers' risk expectations for the future operation of the enterprise, thus reducing the opportunity cost of retaining excess resources in cost management.

TABLE III. REGRESSION RESULTS OF THE RELATIONSHIP BETWEEN EQUITY PLEDGE FUNDS INVESTED IN THIRD PARTIES, EQUITY PLEDGE RATE AND COST STICKINESS

\begin{tabular}{|l|l|}
\hline Variable & Regression \\
\hline Cons & $\begin{array}{c}0.0958^{* * *} \\
(22.47)\end{array}$ \\
\hline$\Delta \operatorname{lnSALES}$ & $0.442^{* * *}$ \\
\hline
\end{tabular}




\begin{tabular}{|c|c|}
\hline Variable & Regression \\
\hline & $(57.10)$ \\
\hline $\begin{array}{l}\text { DEC* } * \ln S A \\
\text { LES }\end{array}$ & $\begin{array}{c}-0.094 * * * \\
(-3.31)\end{array}$ \\
\hline $\begin{array}{l}\text { Plgrate*DEC } \\
* \Delta \operatorname{lnSALES}\end{array}$ & $\begin{array}{c}-0.009 * * * \\
(-5.58)\end{array}$ \\
\hline $\begin{array}{l}\text { Invest*Plgrat } \\
\mathrm{e}^{*} \mathrm{DEC}^{*} \Delta \ln \\
\text { SALES }\end{array}$ & $\begin{array}{r}0.020 * * \\
(2.97)\end{array}$ \\
\hline $\begin{array}{l}\text { AINT*DEC } \\
* \Delta \ln \text { SALES }\end{array}$ & $\begin{array}{l}0.000 \\
(1.16)\end{array}$ \\
\hline $\begin{array}{l}\text { EINT*DEC* } \\
\Delta \operatorname{lnSALES}\end{array}$ & $\begin{array}{c}-0.029 * * * \\
(-3.60)\end{array}$ \\
\hline $\begin{array}{l}\text { FCF*DEC* } \\
\Delta \ln \text { SALES }\end{array}$ & $\begin{array}{l}0.031 \\
(0.22)\end{array}$ \\
\hline F statistic & 557.64 \\
\hline Adjusted R 2 & 0.397 \\
\hline $\mathrm{N}$ & 5917 \\
\hline
\end{tabular}

\section{Conclusion}

Although the causes and economic consequences of cost stickiness is investigate by many scholars, few paper researches on the impact of controlling shareholder financing on cost stickiness. This paper takes the companies with equity pledge in China during the period 2008-2017 as the research object, and empirically tests the relationship between equity pledge and cost stickiness.

The results show that, the higher of the equity pledge rate, the stronger the cost stickiness of enterprises. On the one hand, when the equity pledge rate is high, the internal capital flow is fast and abundant, managers are more inclined to radical business strategies. On the other hand, due to the large amount of money held, coupled with equity pledge, managers tend to be optimistic about the company's future business expectations.

Besides, when the pledge funds are invested in third parties, the impact of equity pledge rate on cost stickiness will be weakened. The following two reasons are contributed to this phenomenon. While the company needs funds for business development, the enterprise will appropriately reduce the committed resources that have been invested. And, facing with the risk of equity transfer delayed, enterprises may have to take a series of measures to reduce these redundant idle resources, thus weakening the cost stickiness of enterprises.

According to the above research results, the following suggestions are proposed for enterprise management:

First, perfect the cost control system of the enterprise as soon as possible, understand the meaning of cost stickiness and make correct use of it. After the equity pledge of the controlling shareholder, attention should be paid to the continuous use of new methods to participate in decision-making, in order to improve decision-making efficiency and reduce risk. Second, pay attention to improving the internal governance of enterprises, especially the improvement of ownership structure, and enhance the level of internal governance.

Of course, there are some limitations in this paper. Future research can focuses on mining the feasibility of more data, and discuss the problems of risk aversion and resource allocation brought about by equity pledge and cost stickiness from multiple angles.

\section{Acknowledgment}

Our thanks to the Business School of Sichuan University for supporting us to use facilities and academic atmosphere. The authors are grateful to the support of National Natural Science Foundation of China (71902128) and Sichuan University Innovation spark project (2018hhf-49).

\section{References}

1. Balakrishnan, R., Labro, E., \& Soderstrom, N. S. (2014). Cost Structure and Sticky Costs. Journal of Management Accounting Research, 26(2), 91-116.

2. Banker, R. D., \& Byzalov, D. (2014). Asymmetric Cost Behavior. Journal of Management Accounting Research, 26(2), 43-79.

3. Banker, R. D., Basu, S., Byzalov, D., \& Chen, J. (2014). The Confounding Effect of Cost Stickiness in Conservatism Research. Social Science Research Network.

4. Banker, R. D., Byzalov, D., Ciftci, M., \& Mashruwala, R. (2014). The Moderating Effect of Prior Sales Changes on Asymmetric Cost Behavior. Journal of Management Accounting Research, 26(2), 221-242.

5. Brüggen, A., \& Zehnder, J. (2014). SG\&A cost stickiness and equity-based executive compensation: does empire building matter? Mathematical Methods of Operations Research, 25(3), 169-192.

6. Habib, A., \& Hasan, M. M. (2019). Corporate Social Responsibility and Cost Stickiness. Business \& Society, 58(3), 453-492.

7. Hao XC, \& Liang Q. (2009). Does Stock Pledge of Ultimate Owner Impair Firm Value? Accounting Research,(07):57-63+96.

8. Jiang W, \& Hu YM. (2011). Enterprise Cost Stickiness: Literature Review and Prospect. Accounting Research,(09):74-79.

9. Jiang W, Hu YM, \& Lv J. (2015). Does Accrualbased Earnings Management Affect Firm Cost Stickiness? Nankai Business Review,18(02):83-91.

10. Kong YS, Zhu NP, \& Kong QG. (2007). Study on Cost Stickiness. Accounting Research,(11):58$65+96$.

11. Li N, \& Zheng GJ. (2015). Stock Pledge and Expropriations of Controlling Shareholders Motivating by Market Capitalization Management. Accounting Research,(05):42-49+94. 
12. Liang SK. (2015). Managers' Overconfidence, Debt Constraints and Cost Stickiness. Nankai Business Review,18(03):122-131.

13. Ma YQ, \& Zhang ZN. (2013). A Study on Financial Crisis Shocks, Managerial Earnings Incentive and Cost and Expense Stickiness. Nankai Business Review,16(06):70-80.

14. Qin, B., Mohan, A. W., \& Kuang, Y. F. (2015). CEO Overconfidence and Cost Stickiness. Management Control \& Accounting, 2015(2), 34-38.

15. Tan Y, \& Wu J. (2013). Does Stock Pledge Have Governance Utility?_Empirical Evidence from Chinese Public Companies. Accounting Research,(02):45-53+95.
16. Xie DR, Liao K, \& Zheng DJ. (2017). Controlling Shareholder' s Share Pledging and Implicit Choice of Development Cost Accounting Policy. Accounting Research,(03):30-38+94.

17. Xie DR, Zheng DJ, \& Cui CY. (2016). Is Controlling Shareholder's Share Pledge a Potential "Mine"?. Management World,(05):128-140+188.

18. Xu SF, He XH, Chen JP. (2016). Stock Pledge and Large Shareholders' Dual Timing Motivations. Journal of Finance and Economics,42(06):74-86.

19. Yang, D. (2015). Mergers, CEO Hubris, and Cost Stickiness. Emerging Markets Finance and Trade, 51, 46-63. 